\title{
Utilization of Industrial Ferronickel Slags as Recycled Concrete Aggregates
}

\author{
Petros Petrounias ${ }^{1,2, *(\mathbb{D})}$, Aikaterini Rogkala ${ }^{1}\left(\mathbb{D}\right.$, Panagiota P. Giannakopoulou ${ }^{1}(\mathbb{D})$, Angeliki Christogerou ${ }^{3}{ }^{(\mathbb{D}}$, \\ Paraskevi Lampropoulou ${ }^{1}$, Spyridon Liogris ${ }^{4}$, Petros Koutsovitis ${ }^{1}\left[\right.$ and Nikolaos Koukouzas ${ }^{2}$ \\ 1 Section of Earth Materials, Department of Geology, University of Patras, 26504 Patras, Greece; \\ krogkala@upatras.gr (A.R.); peny_giannakopoulou@windowslive.com (P.P.G.); \\ p.lampropoulou@upatras.gr (P.L.); pkoutsovitis@upatras.gr (P.K.) \\ 2 Chemical Process \& Energy Resources Institute, Centre for Research \& Technology Hellas (CERTH), \\ 6th km Charilaou-Thermi Rd, 60361 Maroussi, Greece; koukouzas@certh.gr \\ 3 Department of Chemical Engineering, University of Patras, Caratheodori 1, 26504 Patras, Greece; \\ angiechristo@upatras.gr \\ 4 Wasco Coatings Europe BV, Vi.Pe. Thisvis, Domvraina, 32010 Viotia, Greece; \\ spyridon.liogris@wascoenergy.com \\ * Correspondence: geo.plan@outlook.com
}

check for

updates

Citation: Petrounias, P.; Rogkala, A.; Giannakopoulou, P.P.; Christogerou, A.; Lampropoulou, P.; Liogris, S.; Koutsovitis, P.; Koukouzas, N. Utilization of Industrial Ferronickel Slags as Recycled Concrete Aggregates. Appl. Sci. 2022, 12, 2231. https://doi.org/10.3390/app12042231

Academic Editors: Laurent Daudeville, Carlos Morón Fernández and Daniel Ferrández Vega

Received: 16 January 2022

Accepted: 17 February 2022

Published: 21 February 2022

Publisher's Note: MDPI stays neutral with regard to jurisdictional claims in published maps and institutional affiliations.

Copyright: () 2022 by the authors Licensee MDPI, Basel, Switzerland. This article is an open access article distributed under the terms and conditions of the Creative Commons Attribution (CC BY) license (https:// creativecommons.org/licenses/by/ $4.0 /)$.

\begin{abstract}
The scope of this study focuses on the use of two different types of industrial byproducts such as slags (FeNi and Electric Arc Furnace slag) combined with natural sand as concrete aggregates as well as the evaluation of their suitability on the final physicomechanical behavior of the produced concrete specimens. For this reason, twelve concrete specimens were prepared using variable concentrations of these slags which were compared to concrete specimens made by natural rocks as aggregates (limestones). The mineralogical, petrographic, chemical and morphological characteristics of these raw materials were related to the physicomechanical characteristics of the produced concrete specimens. Those concrete specimens containing aggregates of higher amount of Electric Arc Furnace slags seems to present better mechanical strength both in 7 and in 28 days of curing regarding the other mixtures and regarding the specimens made by natural rocks as aggregates (limestones). This is due to the mineralogical, textural and morphological characteristics of the tested slags, which lead to a better bonding between them and the cement paste making them at the same time a promising alternative in the production of green concrete for construction applications. The compact texture of slags is responsible for the stronger bonding with the aggregates in relation to the unevenly distributed porosity of the natural aggregates. Wüstite presents negative effect on the final mechanical strength of concrete specimens which is documented both by the microscope images and by the three-dimensional study of the produced concretes.
\end{abstract}

Keywords: industrial by products; slags; recycled concrete; recycled aggregates

\section{Introduction}

Concrete is the most used and cost-effective construction material in the world with an annual production of about 33 billion tons [1], and in view of the global population growth [2], the usage trend for building new infrastructures is estimated to increase up to $6 \%$ [3]. The basic components of concrete are made up of cement-a mixture of clinker and gypsum, aggregates and water, all of whom significantly affect the workability, durability and mechanical performance of the final product. From the environmental point of view, the cement production technology has a strong impact on energy consumption and increased $\mathrm{CO}_{2}$ levels, $\sim 8 \%$ of the global anthropogenic emissions [4], mainly associated with the high calcination temperature $\left(\sim 1450{ }^{\circ} \mathrm{C}\right)$ of raw materials (limestone and clay minerals) necessary for the cement clinker formation. The latter has the role of the hydraulic binder and is by far the most important ingredient in concrete, constituting about $7 \%$ to $15 \%$ of 
its total volume. Aggregates, on the other hand, also raise environmental concerns related with their extraction and processing as they make up more than the half of the concrete's volume, approximately 60-75\% [5]. Moreover, the quality of the hardened concrete depends upon the suitable use of both fine and coarse aggregates, usually consisting of natural sand and gravel or crushed stone and their efficient bond with the surrounding cement paste. Bearing all this in mind, it is obvious that for the huge concrete volumes produced every year, vast amounts of natural resources are required both for aggregates and cement leading to severe environmental problems.

Based on the ecological footprint caused by the unsustainable linear production model — take, make and dispose - which is clearly impacting climate change, waste management and natural resource depletion, a worldwide challenge have become even more apparent in driving change. Accordingly, a new legally binding agreement was adopted in December 2015 by the United Nations known as the Paris Climate Change Agreement aiming to reduce the greenhouse gas emissions on a global base [6]. The objective of the net-zero $\mathrm{CO}_{2}$ emissions by 2050-2070 applying to heavy industry as well, including the steel, cement, chemicals and other materials sectors. Under this prism, the circular economy initiatives published by the European Commission in March 2020 [7] can certainly offer successful and realistic decarbonization pathways not only in overcoming strict legislation and financial burden, but also in the development of a sustainable future with considerable social and economic benefits in the upcoming years.

One of the targets of the circular economy action plan is waste recycling and industrial by-products utilization, a practice that cement manufacturing industries has already made progress on either through the implementation of different production processes or as well through the adoption of synergy practices.

A great example of the industrial symbiosis is the steel slags valorization that have attracted the construction sector during the last decades as they have the potential to be used as partial replacement of cement clinker due to their pozzolanic characteristics, but as well as aggregates replacement in the formation of concrete. The latter application field though is more favorable as little, or no processing of the aggregates is required against the use as a binder material where grinding of these by-products is prerequisite and associated with high energy consumptions [3]. Thereafter, different types of coarse and/or fine slag aggregates have been investigated for the manufacturing of eco-friendly concrete which may found use in various construction applications such as asphaltic pavement structures, road bases and surfaces or in other concrete shaped applications, e.g., breakwater blocks and dams.

Moreover, the European Waste Framework Directive [8,9] makes clear the importance of industrial by-products valorization such as iron and steel slag aggregates that contributes to waste minimization and resource conservations. Ferrous containing slags, are silicate melts that are formed during the manufacturing of crude steel and crude iron, mainly due to the combination of slagging agents and fluxes used to remove impurities from iron ore and other metal feeds of the smelting furnaces [10]. The hot slags are tapped from the liquid metal and transported to a slag damp where they are stockpiled, after cooling (open-air or water spraying) and processed to solid material. In Europe, $\sim 45 \mathrm{Mt}$ of blast furnace slags and steel slags were produced in 2018 [11], whereas in the U.S., steel slag production is estimated in the range of 8 to $12 \mathrm{Mt}$ [10]. The most common produced metallurgical slags are steel, ferronickel, copper, lead, zinc, phosphorous and stainless steel slags. An important parameter affecting the physical and chemical properties of the slag by-products is by far the source ore and the metal processing method used by each country. Greece for example is the one of the largest ferronickel (FeNi) producer in Europe utilizing the domestic laterite ore deposits [12]. The pyrometallurgical process comprises of two main stages: (a) preheating of the feeding materials in rotary kilns and (b) reduction and smelting $\left(1600-1700{ }^{\circ} \mathrm{C}\right)$ of output calcine in electric arc furnaces (EAFs). This process leads to the production of two co-existing materials: the ferronickel product and the slag. Given the 
fact that the EAF slag produced make up about $80-90 \%$ of the feeds material's mass [13], it is apparent that large quantities are generated, which concerns steel production industries.

During the past decades, extensive work has been published on the utilization of steel slags as alternative aggregates in Portland concretes. Depending on the physical characteristics of the slag aggregates, e.g., density, granulometric size and shape, and the application field of the final product interesting findings are reported by scientists with emphasis on mechanical, physico-chemical and environmental properties of slagcontaining concrete. Durability studies of concrete mixes containing electric arc furnace (EAF) slag aggregates include systematic tests of compressive strength, water penetration, freeze-thaw cycles, leaching tests and chemical reactivity of the slag with the surrounding cement components [3,14-17]. For example, Manso et al. [18] found that the high porosity of EAF slag used in this work reveals a low-quality concrete in terms of freezing resistance, thus suggesting the additional use of specific admixtures. Leaching tests, on the other hand, showed a beneficial cloistering effect of fluorides and chromium in the concrete mix. In a recent study, conducted by Chatzopoulos et al. [19], conventional sand and gravel were replaced by EAF and ladle furnace (LD) slags, individually or in combination, resulting in the production of a durable concrete. From the 14 test samples prepared, all quality indexes investigated remained either stable or improved in comparison to the reference concrete. The most efficient mixture was achieved when sand was replaced with $30 \%$ by volume of EAF and LD slag sand, respectively, and gravel by $50 \%$ of EAF gravel aggregates leading to concretes with reduced carbonate and chloride penetration. However, granulated blast furnace slags (GBFS) attract also special scientific interest as due to their finer grain size they can be utilized instead of natural fine aggregates (e.g., river sand). Patra et al. [20] for examples state that incorporation of GBFS ( $<5 \mathrm{~mm})$ up to $40 \%$ was feasible, whereas higher percentages (up to $60 \%$ ) lead to reduced workability of the concrete mixes attributed to the higher water absorption of GBFS. Nevertheless, the authors suggest the use of superplasticizers to achieve the appropriate workability as compressive strength shows increased values (up to $45 \mathrm{MPa}$ ) in case of $60 \%$ replacement most probably due to the pozzolanic effect of the steel slag used. An interesting experimental approach on the production of an eco-friendly concrete was done by Anastasiou et al. [21] aiming on the maximum valorization of alternative raw materials. Fly ash was incorporated as cement replacement, EAF slag and recycled aggregates from construction demolition wastes (CDW) as coarse and fine aggregates, respectively. They found that the use of CDW increases the porosity of concrete with subsequent decrease in strength and durability compared to a reference mix, while the synergy of CDW with EAF slag partly overcomes these drawbacks reaching compressive strength values of about $30 \mathrm{MPa}$ at 28 days. In spite the poor bonding between aggregate-binder, the formed concrete might be used in lowerdemand applications. Blended concretes have been also studied using FeNi slag aggregates in different grain sizes and by substituting ordinary binding materials as presented for example by Kim et al. [22]. They found that early strength of the test samples was affected, but with time hydration reaction can overcome this issue. According to Sun et al. [23], natural aggregates can feasibly be replaced by FeNi slag as the final concrete mix conforms with type $\mathrm{C} 50$ due to the obtained mechanical strength reaching $55 \mathrm{MPa}$ at 28 days of curing. However, best engineering results are observed with the use of blast furnace slag as well. Lately, Nuruzzaman et al. [24] investigated the combined use of FeNi slag and ground FeNi slag as supplementary binder for enhancing the sustainability of self-compacting concrete. After assessing strength, permeability and microstructure of the produced concrete samples, they came to the conclusion that a replacement of cement up to 30\% by ground FeNi slag and, respectively, of sand by $50 \%$ replacement of FeNi slag is feasible as they presented high durability.

There is still room for further research on the production of eco-friendly concretes from different types of slags and / or other industrial by-products in relation to the technical properties of the new concrete mixes as for sure environmental benefits are anticipated. As the economy and the smelting industry developed rapidly, the quantity of smelter slag has 
been increasing for a long time. Common smelting furnace slag includes steel smelting slag, red mud, copper smelting slag, lead slag, ferronickel slag, sulfuric acid slag, etc. Approximately 30 million tons of ferronickel slag are emitted each year, accounting for more than a fifth of the global production $[3,25,26]$. The large stockpiles of nickel slag not only occupy land and pollute the environment, but also bring about severe challenges to the sustainable development of the nickel smelting industry [27,28]. Furthermore, it is essential to develop and utilize smelter slag through environmental-friendly technologies $[29,30]$. Different types of industrial by-products were studied in the past few decades in order to find suitable alternatives of natural sand in concrete. Blast furnace slag, steel slag, copper slag, foundry slag and ferronickel slag are the most common types of by-product slags that can be used as fine aggregate in concrete. Rashad et al. [31] showed that the use of blast furnace slag as a replacement of natural sand improved the compressive strength of mortar. The physical and chemical properties of the by-product slag can vary significantly depending on the type of the ore, the smelting process and temperature, and the cooling method. The amount of literature available on the use of ferronickel slag in concrete is very limited. Sato et al. [32] pointed out that freeze-thaw resistance of concrete decreased with the use of $50 \%$ ferronickel slag replacing natural coarse aggregate. The reason was attributed to the increase of bleeding and the resulting reduction in air content of concrete with the increase of ferronickel slag. Tomosawa et al. [33] pointed out a deleterious expansion due to the alkali-silica reaction of concrete containing $50 \%$ ferronickel slag aggregate and recommended to use low alkali cement to mitigate this expansion. Improved frost resistance of concrete was reported by the partial or full replacement of sand by ferronickel slag aggregate $[34,35]$ showed that ferronickel slag could be used as a suitable replacement of natural aggregates in hot mix asphalt and in base and sub-base layers of roads. It was also reported that ferronickel slag could be used to make composites with waste glass. These composites were described as safe to use as any toxic elements in the slag were chemically locked in the composite [36].

It can be observed from the above literature review that utilization of ferronickel slags from different sources was attempted in different applications. The aim of this study is double. From the one hand is the significant improvement of the sustainability of concrete production by reducing the use of natural aggregates and simultaneously by the increase of use of industrial by-products (i.e., slags) enhances the green policy of industries as well as their financial benefits. On the other hand, by the prediction of the concrete behavior through the tools of petrography and mineralogy the human footprint on the environment reduces. A comprehensive study is necessary in order to understand the properties of concrete using these aggregates. The workability of fresh concrete, physic-mechanical properties of hardened concrete using these aggregates as a supplementary cementing material are evaluated in this study. Thus, this work presents an innovative study on a green concrete using two industrial by-products evaluating the engineering properties.

\section{Materials and Methods}

The present study emerged after the constructive cooperation of research institutions with industrial companies having as main goal their interconnection and in order to bring significant results both in constructions and in the wider society through the reuse of slags as high-quality aggregates.

\subsection{Materials}

In this study, the morphological and mechanical characteristics of alternative aggregates (slags) of variable concentrations were evaluated for their use as concrete aggregates and linked with the performance of the resultant produced high-strength concrete specimens. More specifically, the alternative aggregates were FeNi and Electric Arc Furnace slags. Furthermore, micritic limestone was used as concrete aggregate in order to produce specimens containing only natural aggregates (standard concrete). Moreover, cement of Type II ASTM C 150 (Lafarge) [37] was used as well as potable tap water, free of impurities 
such as salt, silt, clay and organic matter, was also used for mixing and curing the concrete. The $\mathrm{pH}$ value of water was 7.0. Natural washed sand was also used for the concrete production whose concentration varies from 5.5 to $7.5 \%$. The water/cement ratio was 0.33 .

\subsection{Methods}

\subsubsection{Methods for Raw Materials}

The mineralogical and textural characteristics of the used raw materials were examined in polished thin sections with a polarizing microscope according to EN-932-3 [38] standard for petrographic description of aggregates. Thin sections were prepared to study the mineralogical composition and textural characteristics of the studied materials. The thin sections were examined under a petrographic microscope (Leitz Ortholux II POL-BK Ltd., Midland, ON, Canada) for mean grain size and grain shape. The bulk mineral composition of the studied samples was also determined by X-ray Diffraction (XRD), using a Bruker D8 advance diffractometer, with Ni-filtered $\mathrm{CuK} \alpha$ radiation. Random powder mounts were prepared by gently pressing the powder into the cavity holder. The scanning area for bulk mineralogy of specimens covered the $2 \theta$ interval $2-70^{\circ}$, with a scanning angle step size of $0.015^{\circ}$ and a time step of $0.1 \mathrm{~s}$. The mineral phases were determined using the DIFFRACplus EVA $12{ }^{\circledR}$ software (Bruker-AXS, Gmbtl, Karlsruhe, Germany) based on the ICDD Powder Diffraction File of PDF-2 2006. Furthermore, loss on ignition (LOI) of the studied samples was determined according to the ASTM D7348-13 standard [39]. Additionally, an XRF (X-ray Fluorescence) spectrometer and a sequential spectrometer cited at the Laboratory of Electron Microscopy and Microanalysis (University of Patras, Greece) were used for the determination of the major and trace elements of the studied zeolite. An amount of $0.8 \mathrm{~g}$ of dried ground sample was mixed with $0.2 \mathrm{~g}$ of wax (acting as binder) and was pressed to a pellet under 15 tones. Pressed pellets were analyzed with a RIGAKU ZSX PRIMUS II spectrometer, which is equipped with Rh-anode. In order to examine the mineralogical and textural characteristics of the tested slags, a scanning electron microscope (JEOL JSM-6300 SEM) equipped with energy dispersive (EDS: Model: 6699, Det. Area: $10 \mathrm{~mm}^{2}$, Resol.: $138 \mathrm{eV}$ ) using the INCA software was used. The scanning electron microscope used is located in the Laboratory of Electron Microscopy and Microanalysis (University of Patras, Greece). Operating conditions were accelerating voltage $25 \mathrm{kV}$ and beam current $3.3 \mathrm{nA}$, with a $4 \mu \mathrm{m}$ beam diameter. The total counting time was $60 \mathrm{~s}$ and dead-time $40 \%$. Synthetic oxides and natural minerals were used as standards for the analyses, where the detection limits are $\sim 0.1 \%$ and accuracy better than $5 \%$ was obtained. Moreover, the specific gravity of the raw materials (slags) used as aggregates were calculated according to ASTM C1567 standard [40].

\subsubsection{Methods for the Produced Concrete}

Twelve concrete cylindrical specimens were made from two different types of slags and three standard concretes were made containing natural aggregates (limestones) according to ACI-211.1-91 [41]. The aggregates were crushed through standard sieves a separated into the size classes of 2.00-4.75, 4.45-9.5 and 9.5-19.1 mm. After $24 \mathrm{~h}$, the samples were removed from the mold and were cured in water for 28 days. Curing temperature was $20 \pm 3{ }^{\circ} \mathrm{C}$. In the present study, concrete mixtures were prepared with variations in the quantitative proportions of the different types of slags as shown in Figure 1 and Table 1.

These specimens were tested in a compression testing machine. The compressive strength of concrete is calculated by the division of the value of the load at the moment of failure over the area of specimen both at 7 and 28 days. In this work, our aim was to study the process of hydration of cement at 7 and 28 days because they are the key days to come up to a reliable conclusion on a micro scale regarding the relationship of cement paste with aggregates in concrete, especially comparing different mixtures of raw materials. The compression test was elaborated according to ASTM C42/C42M-12 [42] in a compressive strength Pilot machine-Controls (Model C13C02) with maximum load $1500 \mathrm{kN}$ (Figure 2a). The cylindrical specimens used for this test had $50 \mathrm{~mm}$ diameter and 
$55 \mathrm{~mm}$ high (Figure $2 \mathrm{~b}$ ). After the compressive strength test, the textural characteristics of concretes were examined. Polished thin sections were studied in a polarizing microscope according to ASTM C856-17 [43]. The surface texture of aggregate samples was studied by using Secondary Electron Images (SEI) according to BS 812 Part 1 [44] which outlines six qualitative categories, e.g., glassy, smooth, granular, rough, crystalline, honeycomb and porous. Furthermore, two physical properties of the produced concrete specimens were calculated, the water absorption as well as the density according to ASTM Standard C642 [45].

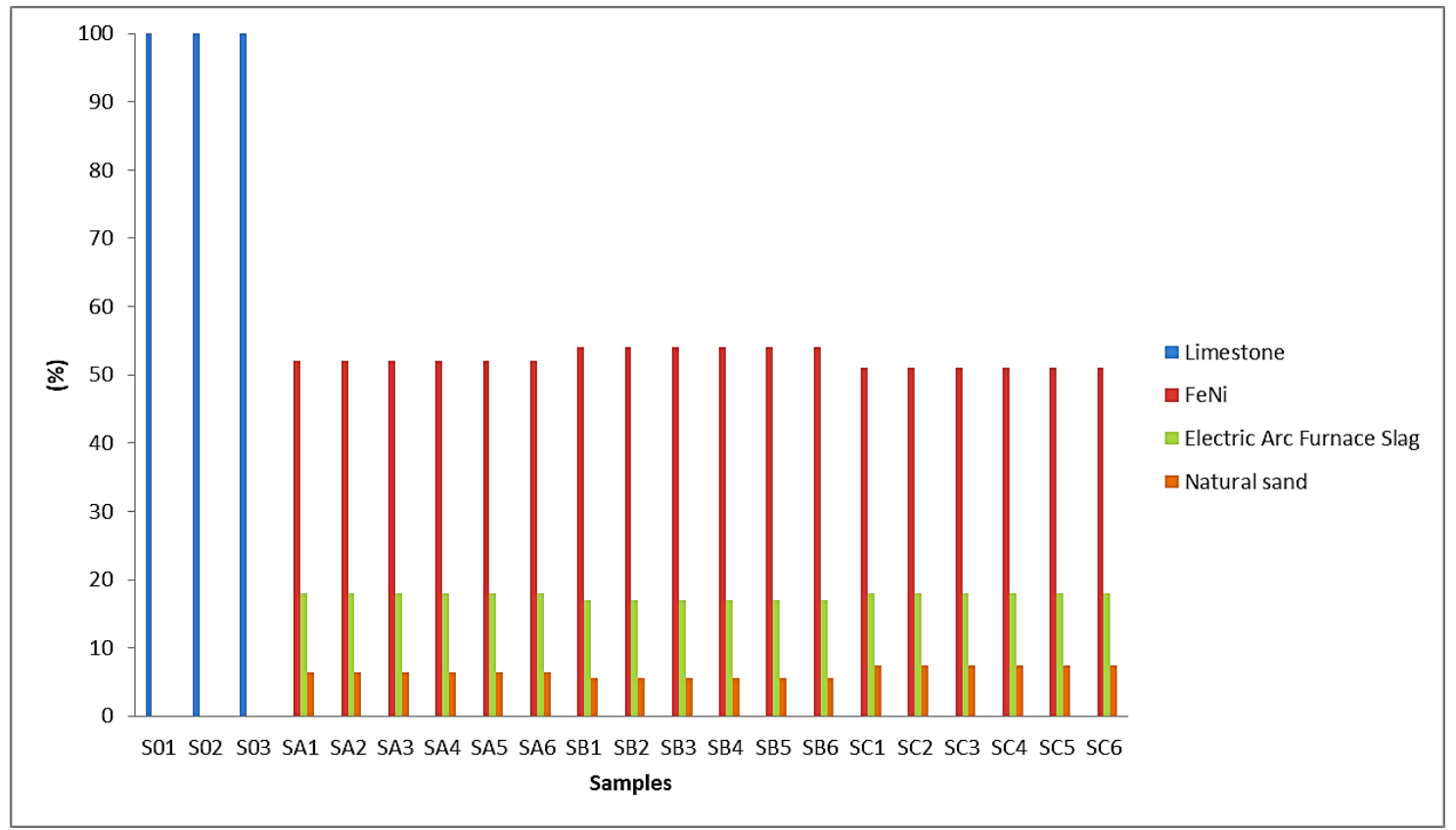

Figure 1. Results of the aggregates' concentration of concrete samples.

Table 1. Aggregates' concentration of concrete samples.

\begin{tabular}{ccccc}
\hline Samples & Limestone (\%) & FeNi (\%) & $\begin{array}{c}\text { Electric Arc } \\
\text { Furnace Slag (\%) }\end{array}$ & Natural Sand (\%) \\
\hline S01 & 100 & - & - & - \\
S02 & 100 & - & - & - \\
S03 & 100 & - & - & 6.5 \\
SA1 & - & 52 & 18 & 6.5 \\
SA2 & - & 52 & 18 & 6.5 \\
SA3 & - & 52 & 18 & 6.5 \\
SA4 & - & 52 & 18 & 6.5 \\
SA5 & - & 52 & 18 & 6.5 \\
SA6 & - & 52 & 18 & 5.5 \\
SB1 & - & 54 & 17 & 5.5 \\
SB2 & - & 54 & 17 & 5.5 \\
SB3 & - & 54 & 17 & 5.5 \\
SB4 & - & 54 & 17 & 5.5 \\
SB5 & - & 54 & 17 & 7.5 \\
SB6 & - & 54 & 18 & 7.5 \\
SC1 & - & 51 & 18 & 7.5 \\
SC2 & - & 51 & 18 & 7.5 \\
SC3 & - & 51 & 18 & 7.5 \\
SC4 & - & 51 & 18 & 7.5 \\
SC5 & - & 51 & 18 & \\
SC6 & - & 51 & & \\
\hline
\end{tabular}




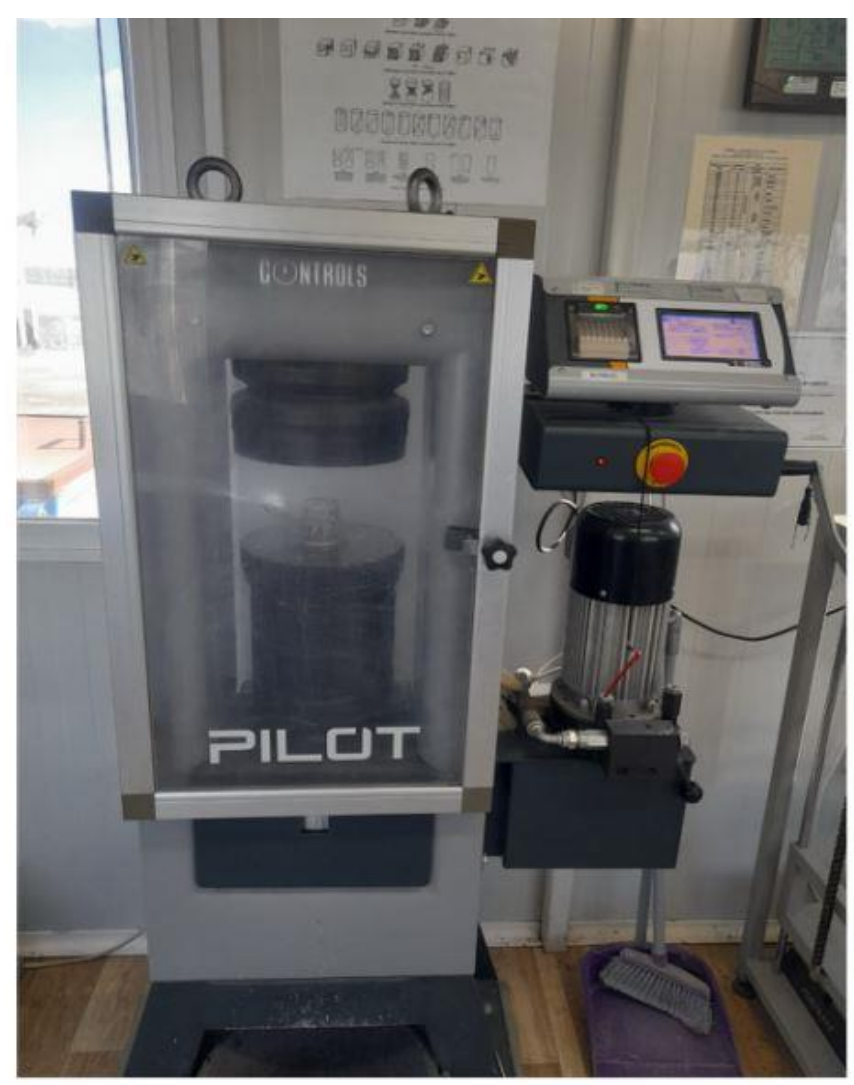

(a)

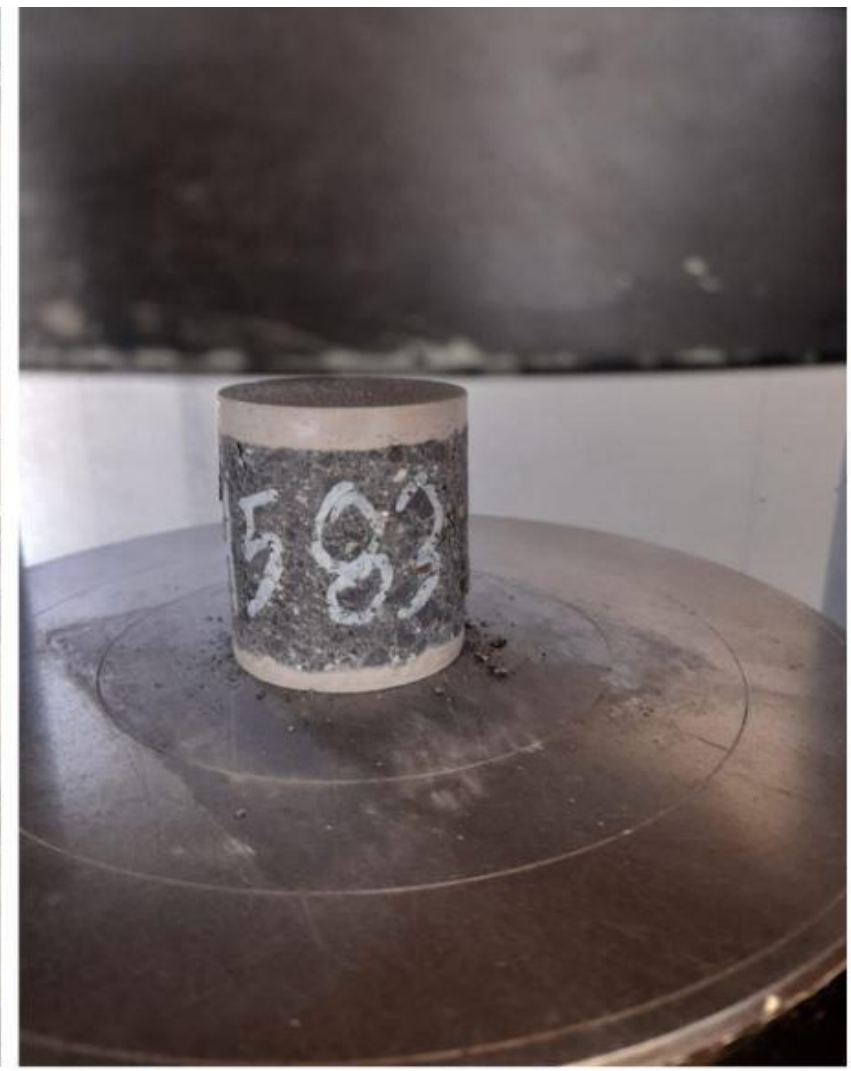

(b)

Figure 2. (a) The compressive strength test machine. (b) Cylindrical concrete specimen.

In this stage, the examination of the concrete textural features was carried out when using polished thin sections in a petrographic microscope (ASTM C856-17) [43]. A 3D depiction of the petrographic characteristics of the concrete as well as of the studied slags was carried out by the 3D Builder software using thin sections.

\section{Results}

\subsection{Raw Materials Characterization}

The microscopic observation of the studied slags under polarizing microscope is in accordance with the results of the X-ray diffraction analysis. In general, the studied slags present heterogeneous texture due to uneven aggregate of minerals or usually multi organic fragments. Slags are rich in opaque minerals, mainly wustite and spinels, while microcrystalline to cryptocrystalline, mainly anisotropic calcium-alumino silicate phases, as well as silica minerals complete the overall mineral composition (Figure $3 a-c)$. Alternations of isotropics with anisotropic minerals that form banded structures are also observed. Some grains display different composition around their margins and more specifically they present microcrystalline material possibly alumina-calcium-silicate (anisotropic) in coexistence with an amorphous mass (isotropic). The shape of the opaque minerals and of those of the spinel group usually appears polygonal to spherical with peculiar-sub-dominated plains. The spinel group minerals appear more with dark brown or red to black color and less amber, which indicate their more ferritic-chromit character and less aluminum (Figure 3d). The anisotropic minerals predominate in a prismatic shape, euhedral or subhedral with the exception of silicon dioxide ores which are usually unhedral. Anisotropic minerals usually appear with gray, white and yellow colors, while olivine crystals were observed less frequently (Figure 3a). 

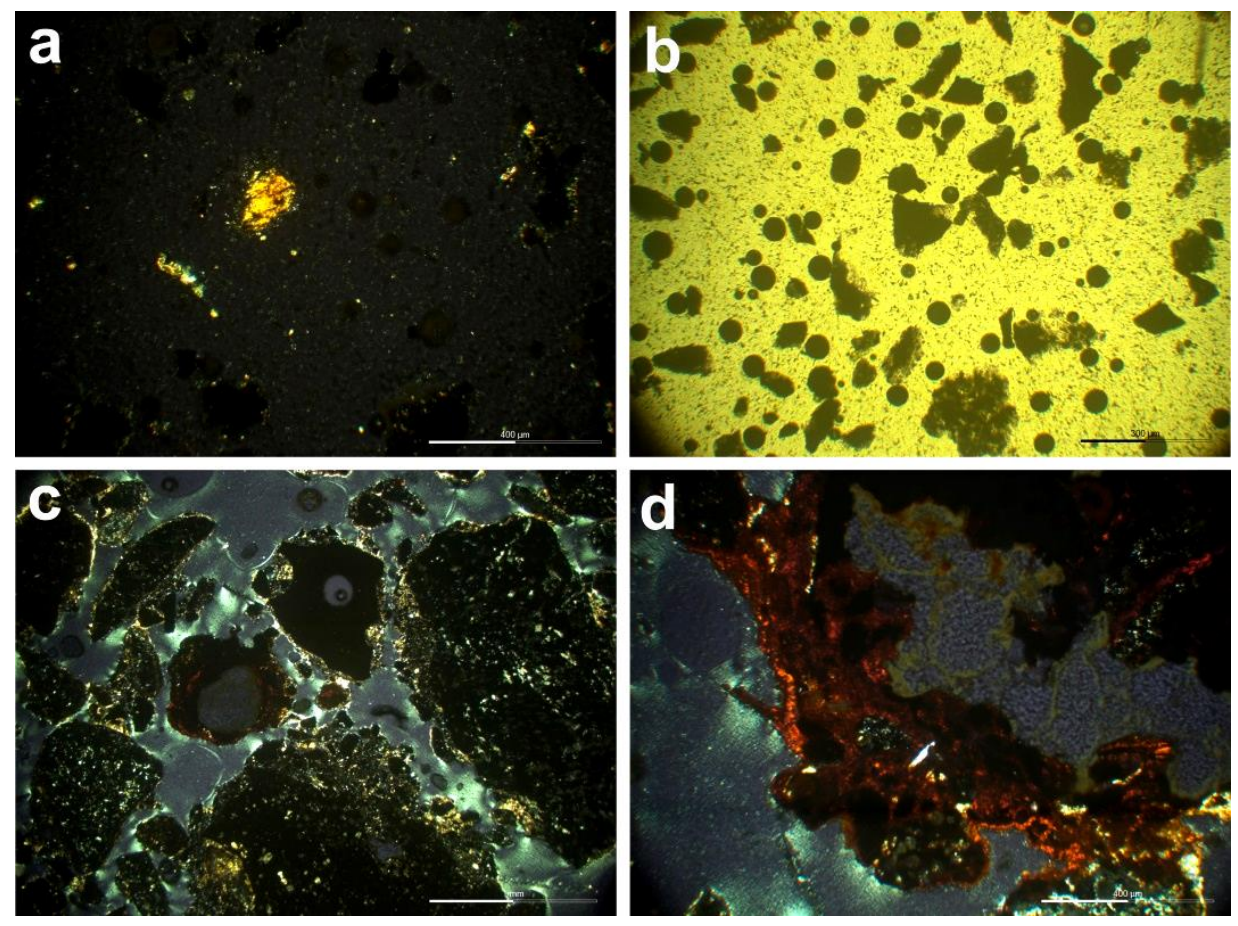

Figure 3. Representative photomicrographs of the studied slags showing: $(\mathbf{a}, \mathbf{b})$ anhedral olivine, spherical crystals of wïstite, spinels and microcrystalline opaque minerals in FeNi slag (XPL and PPL Nicols, respectively); (c) grains of spinels, wüstite, calc-aluminosilicate and silicon dioxide phases in Electric Arc Furnace slag (XPL Nicols); and (d) elongated and curved ferritchromit in Electric Arc Furnace slag (XPL Nicols).

The carbonate aggregates (limestones) used as components of the produced concrete specimens do not present many cracks or impurities in their structure as can be seen from the petrographic study. More specifically, limestones used display micritic texture with numerous of fossils and veinlets of microcrystalline calcite and stylolitic porosity filled with clay minerals and Fe-oxides (Figure 4a,b).
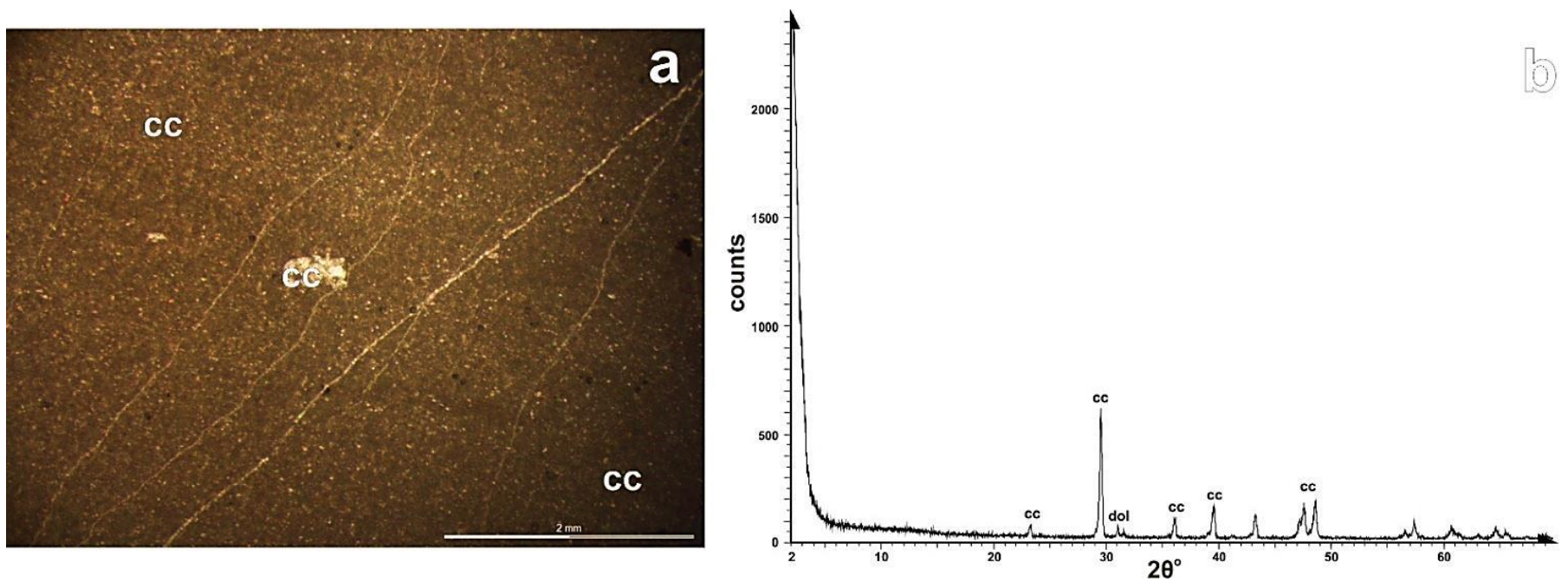

Figure 4. (a) Stylolitic porosity filled with clay minerals and Fe-oxides, fossils and dense network of veins in a micritic limestone; (b) XRD pattern of micritic limestone. Abbreviations: cc: calcite, dol: dolomite. 
The results of the qualitative and semi-quantitative analysis of the tested slags are presented in Tables 2 and 3 and Figure 5a,b. Similar qualitative phase composition was detected in the studied samples with mainly quantitative variations. In general, wüstite, spinel group minerals and lime-alumino silicate phases constitute their modal composition. The highest percentages of the wüstite-spinel phases occur in FeNi slag, which reflects to the geochemical effects, as it contains the lowest percentages of calcium, silicon and higher levels of Fe. Indications derived from the mineralogical analysis of the samples for participation of amorphous phase in their mass in percentages up to $20-30 \%$.

Table 2. ${ }^{* * *}$ Mineral composition $\%$ of the studied FeNi slag.

\begin{tabular}{ccc}
\hline Name & Chemical Formula & Percentages (\%) \\
\hline Spinel group & $(\mathrm{Mg}, \mathrm{Fe}, \mathrm{Mn}, \mathrm{Ni})(\mathrm{Cr}, \mathrm{Al}, \mathrm{Fe}, \mathrm{V}) \mathrm{O}_{4}$ & 35 \\
Wustite & $\mathrm{FeO}$ & 45 \\
Merwinite & $\mathrm{C}_{3} \mathrm{MS}_{2}$ & 7 \\
Beta dicalcium silicate & $\mathrm{C}_{2} \mathrm{~S}$ & 11 \\
Gehlenite & $\mathrm{C}_{2} \mathrm{AS}$ & $<3$ \\
\hline
\end{tabular}

$\overline{* * *}$ In the semi-quantitative analysis, the amorphous phases are not included. It was calculated $<30 \%$.

Table 3. ${ }^{* * *}$ Mineral composition \% of the studied Electric Arc Furnace slag.

\begin{tabular}{ccc}
\hline Name & Chemical Formula & Percentages (\%) \\
\hline Spinel group & $(\mathrm{Mg}, \mathrm{Fe}, \mathrm{Mn}, \mathrm{Ni})(\mathrm{Cr}, \mathrm{Al}, \mathrm{Fe}, \mathrm{V}) \mathrm{O}_{4}$ & 27 \\
Wustite & $\mathrm{FeO}$ & 30 \\
Merwinite & $\mathrm{C}_{3} \mathrm{MS}{ }_{2}$ & 5 \\
Beta, gamma dicalcium silicate & $\mathrm{C}_{2} \mathrm{~S}$ & 18 \\
Gehlenite & $\mathrm{C}_{2} \mathrm{AS}$ & 17 \\
Quartz & $\mathrm{SiO}_{2}$ & $<2$ \\
periclase & $\mathrm{MgO}$ & $<2$ \\
\hline *** In the &
\end{tabular}
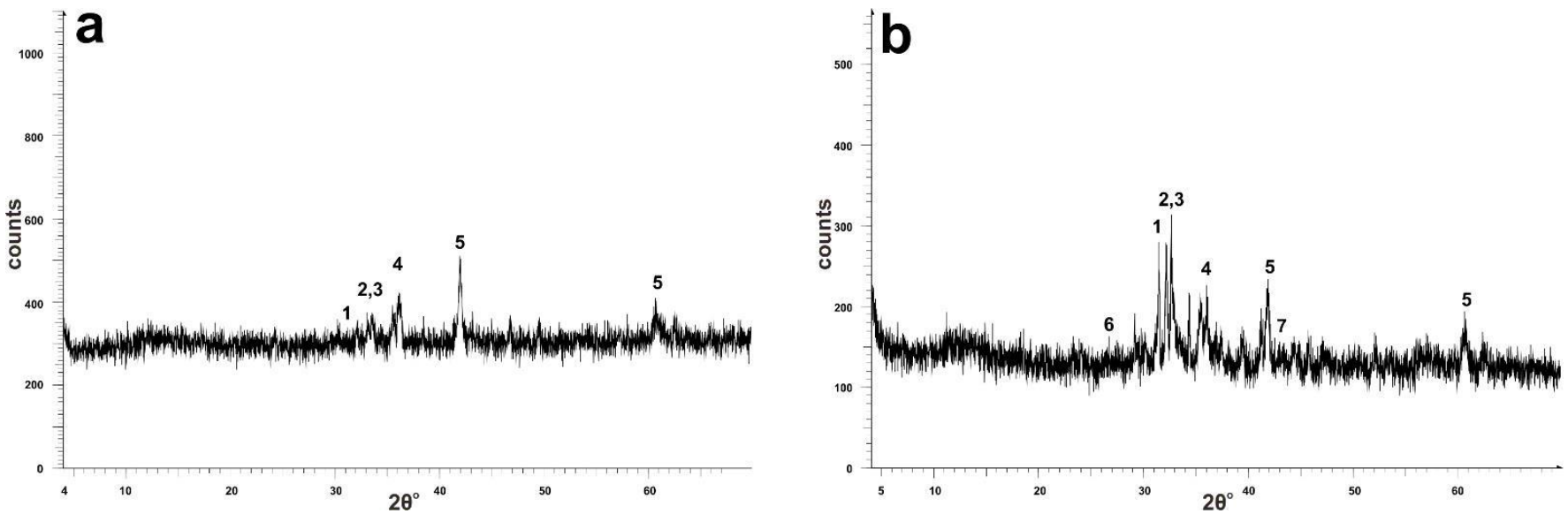

Figure 5. (a) XRD pattern of FeNi slag; (b) XRD pattern of Electric Arc Furnace slag (1: Gehlenite, 2: $\mathrm{C}_{3} \mathrm{MS}_{2}, 3: \mathrm{C}_{2} \mathrm{~S}$, 4: Spinel, 5: Wüstite, 6: Quartz, 7: Periclase).

Results of the chemical composition analyses of the studied slag samples were performed by X-ray Fluoroscence (XRF) are presented in Table 4. The results of XRF analyses shows that the FeNi slag contains higher amount of $\mathrm{Fe}_{2} \mathrm{O}_{3}$ (37.25 wt.\% compared to the ELECTRIC ARC FURNACE SLAG slag (10.41 wt.\%). The ELECTRIC ARC FURNACE SLAG slag displays higher amounts of $\mathrm{SiO}_{2}, \mathrm{Al}_{2} \mathrm{O}_{3}$ and $\mathrm{CaO}(11.81 \mathrm{wt} . \%, 7.29 \mathrm{wt} . \%$ and $26.85 \mathrm{wt} . \%$, respectively) in contrast to FeNi slag which contains significantly lower amounts (3.77 wt.\%, $0.43 \mathrm{wt} . \%$ and $10.21 \mathrm{wt} . \%$, respectively). Regarding the alkalies, they are not significant differences between the two types of slags (Table 3). ELECTRIC ARC FURNACE 
SLAG slag presents LOI (loss on ignition) 1.21, while the FeNi slag does not present any value of LOI. As for the trace elements, FeNi slag is more enriched in Ni, while ELECTRIC ARC FURNACE SLAG slag is more enriched in Cr, Sr, Ba and V (Table 4).

Table 4. Results of the chemical composition of the tested samples ( $<$ DL: <below detection limit).

\begin{tabular}{|c|c|c|}
\hline Oxides & $\mathrm{FeNi}$ & ELECTRIC ARC FURNACE SLAG \\
\hline $\mathrm{SiO}_{2}$ & 3.77 & 11.81 \\
\hline $\mathrm{TiO}_{2}$ & 0.02 & 0.57 \\
\hline $\mathrm{Al}_{2} \mathrm{O}_{3}$ & 0.43 & 7.29 \\
\hline $\mathrm{Fe}_{2} \mathrm{O}_{3} \mathrm{t}^{\mathrm{t}}$ & 37.25 & 10.41 \\
\hline $\mathrm{MnO}$ & $<\mathrm{DL}$ & 1.74 \\
\hline $\mathrm{MgO}$ & 2.30 & 1.74 \\
\hline $\mathrm{CaO}$ & 10.21 & 26.85 \\
\hline $\mathrm{Na}_{2} \mathrm{O}$ & 0.04 & 0.10 \\
\hline $\mathrm{K}_{2} \mathrm{O}$ & 0.04 & 0.03 \\
\hline $\mathrm{P}_{2} \mathrm{O}_{5}$ & 0.33 & 0.39 \\
\hline LOI & 0 & 1.21 \\
\hline \multicolumn{3}{|l|}{ ppm } \\
\hline $\mathrm{Cr}$ & 2561 & 4537 \\
\hline $\mathrm{Co}$ & 379 & 31 \\
\hline $\mathrm{Ni}$ & 1327 & 20 \\
\hline $\mathrm{Cu}$ & 27 & 156 \\
\hline $\mathrm{Zn}$ & 12 & 115 \\
\hline $\mathrm{Rb}$ & $<\mathrm{DL}$ & $<\mathrm{DL}$ \\
\hline $\mathrm{Sr}$ & 39 & 486 \\
\hline $\mathrm{Y}$ & 15 & 34 \\
\hline $\mathrm{Zr}$ & $<\mathrm{DL}$ & 86 \\
\hline $\mathrm{Nb}$ & $<\mathrm{DL}$ & $<\mathrm{DL}$ \\
\hline $\mathrm{Pb}$ & $<\mathrm{DL}$ & $<\mathrm{DL}$ \\
\hline $\mathrm{Ba}$ & 171 & 1203 \\
\hline $\mathrm{V}$ & 31 & 207 \\
\hline $\mathrm{W}$ & 37 & 28 \\
\hline $\mathrm{La}$ & 1 & 12 \\
\hline $\mathrm{Ce}$ & 58 & 94 \\
\hline Th & $<\mathrm{DL}$ & $<\mathrm{DL}$ \\
\hline $\mathrm{Sc}$ & $<\mathrm{DL}$ & $<\mathrm{DL}$ \\
\hline
\end{tabular}

The slags have basicity value which range from 2.42 (ELECTRIC ARC FURNACE SLAG) to 3.31 (FeNi) which as calculated according to the following equation:

$$
\text { Basicity }=(\% \mathrm{CaO}+\% \mathrm{MgO}) / \% \mathrm{SiO}_{2}
$$

where $\% \mathrm{CaO}, \% \mathrm{MgO}$ and $\% \mathrm{SiO}_{2}$ are the contents of those mentioned oxides ( $\mathrm{wt} \%$ ) in the studied slags.

Analyses with Scanning Electron Microscope (SEM) and Energy Dispersive X-ray mapping were conducted to determine the distributions of several major elements ( $\mathrm{Si}$, $\mathrm{Al}, \mathrm{Ca}, \mathrm{Mg}, \mathrm{Fe}, \mathrm{Cr}, \mathrm{K}$ and $\mathrm{Na}$ ) in the studied slags. SEM observations are in accordance with the petrographic features and XRD analyses as indicated in Figure 5 where spherical crystals of wïstite and curved subhedral spinels are shown. These minerals are surrounded by microcrystalline calc-silicate phases $\left(\mathrm{C}_{2} \mathrm{~S}\right)$. FeNi slag presents uniformly distributed porosity of brick type (Figure 6). Regarding ELECTRIC ARC FURNACE SLAG slag, in Figure 7 it is proved that it consists of spherical crystals of wüstite, elongated spinels, calc-silicate phase $\left(\mathrm{C}_{2} \mathrm{~S}\right)$ and microcrystalline gehlenite (Figure 7a). 

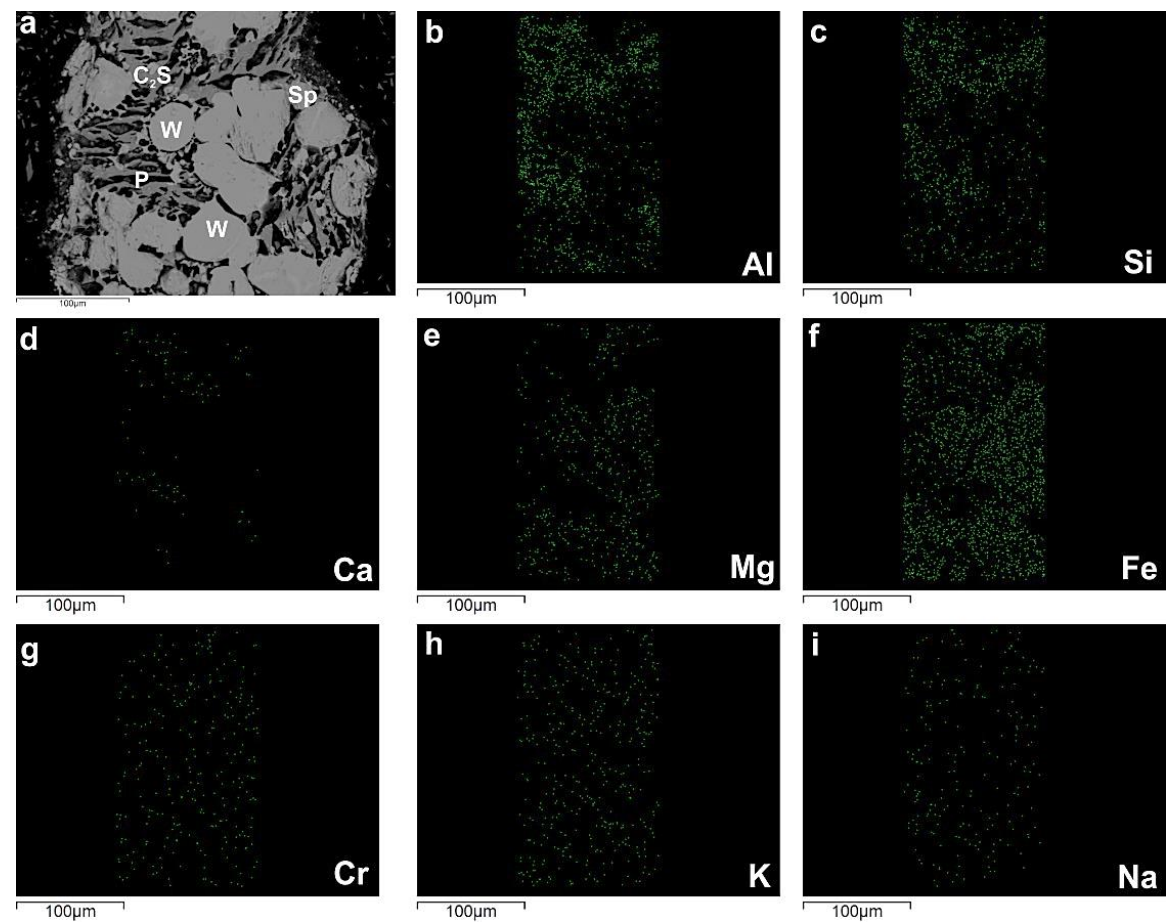

Figure 6. Back-scattered electron image of spherical crystals of wüstite (W), spinels (Sp) and microcrystalline calc-silicate phase $\left(\mathrm{C}_{2} \mathrm{~S}\right)$, as well as pores ( $\mathrm{P}$, distinguished as black) in FeNi slag (a) and mapping of major elements ( $\mathrm{Al}, \mathrm{Si}, \mathrm{Ca}, \mathrm{Mg}, \mathrm{Fe}, \mathrm{Cr}, \mathrm{K}$ and $\mathrm{Na}$, respectively) (b-i).
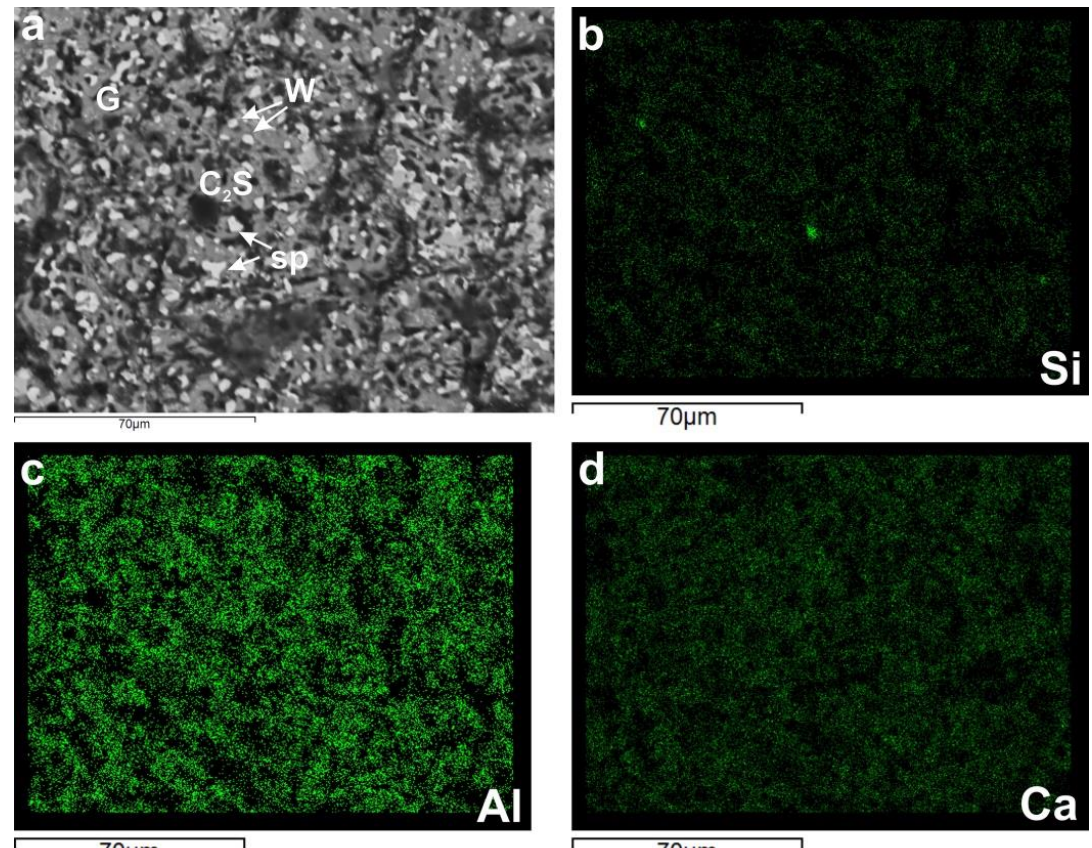

Figure 7. Back-scattered electron image of spherical crystals of wüstite (W), spinels (sp), calc-silicate phase $\left(\mathrm{C}_{2} \mathrm{~S}\right)$ and microcrystalline gehlenite $(\mathrm{G})$ in ELECTRIC ARC FURNACE SLAG slag (a) and mapping of major elements ( $\mathrm{Si}, \mathrm{Al}$ and $\mathrm{Ca}$, respectively) $(\mathbf{b}-\mathbf{d})$.

The results of SEM-X-ray mapping are presented in Figures 6 and 7. The SEM-X-ray mapping analysis result in FeNi slag indicates that Fe is uniformly distributed on the entire surface of the slag (Figure 6f). In addition to $\mathrm{Mg}$, components in the slag that are in lower amounts are $\mathrm{Si}, \mathrm{Cr}, \mathrm{Ca}, \mathrm{K}$ and $\mathrm{Na}$ (Figure $6 \mathrm{~b}-\mathrm{e}, \mathrm{g}-\mathrm{i}$ ). Regarding ELECTRIC ARC FURNACE SLAG slag, the mapping results are in accordance with the chemical compositions and the 
petrographic results. More specifically, slag composition is relatively uniform, in which $\mathrm{Ca}$ and $\mathrm{Al}$ are present as the major component of the slag, while $\mathrm{Si}$ is in smaller amounts (Figure $7 b-d)$.

The specific gravity of the tested slags (both of two types) and of the natural aggregates (limestone) is identified. As can be seen from Table 5, the specific gravity of FeNi slags presents higher values than of those of ELECTRIC ARC FURNACE SLAG slags in all tested samples. More specifically, as for the SA group, its specific gravity values range from 4.51 to $4.61 \mathrm{~T} / \mathrm{m}^{3}$ regarding FeNi slags while from 3.59 to $3.61 \mathrm{~T} / \mathrm{m}^{3}$ regarding ELECTRIC ARC FURNACE SLAG slags. Similarly, the values range of SB group is from 4.54 to 4.59 and from 3.52 to 3.70 in FeNi and ELECTRIC ARC FURNACE SLAG slags respectively. As for the SC group, the range of specific gravity values is from 4.59 to 4.72 and from 3.45 to 3.70 in FeNi and ELECTRIC ARC FURNACE SLAG slags, respectively. The lowest value of this property is found in a FeNi slag of SC group, while the highest value in ELECTRIC ARC FURNACE SLAG slags of SB and SC groups. Regarding the measured specific gravity of the tested limestones used as concrete aggregates is $2.70 \mathrm{~T} / \mathrm{m}^{3}$, intensively lower than that of the investigated slags.

Table 5. Results of the specific gravity test of the tested slags.

\begin{tabular}{ccc}
\hline Samples & Specific Gravity $\left(\mathbf{T} / \mathbf{m}^{3}\right)$ of FeNi & $\begin{array}{c}\text { Specific Gravity }\left(\mathbf{T} / \mathbf{m}^{3}\right) \mathbf{~ o f ~} \\
\text { Electric Arc Furnace Slag }\end{array}$ \\
\hline S01 & 2.70 (limestone) \\
S02 & 2.70 (limestone) \\
S03 & 2.70 (limestone) & 3.61 \\
SA1 & 4.51 & 3.61 \\
SA2 & 4.51 & 3.59 \\
SA3 & 4.61 & 3.61 \\
SA4 & 4.51 & 3.61 \\
SA5 & 4.51 & 3.59 \\
SA6 & 4.61 & 3.52 \\
SB1 & 4.59 & 3.70 \\
SB2 & 4.54 & 3.60 \\
SB3 & 4.56 & 3.52 \\
SB4 & 4.59 & 3.70 \\
SB5 & 4.54 & 3.60 \\
SB6 & 4.56 & 3.45 \\
SC1 & 4.59 & 3.51 \\
SC2 & 4.62 & 3.56 \\
SC3 & 4.70 & 3.61 \\
SC4 & 4.72 & 3.70 \\
SC5 & 4.71 & 3.70 \\
SC6 & 4.69 & \\
\hline
\end{tabular}

\subsection{Results of Concrete Specimens}

Regarding the physical properties of investigated concrete specimens such as density, concrete specimens produced by natural aggregates (limestones) show density from 2621 to $2709 \mathrm{~kg} / \mathrm{m}^{3}$ (Figure 8a, Table 6). As for the specimens made from various percentages of two different slags (FeNi and ELECTRIC ARC FURNACE SLAG), samples of SA group present values of density range from 3093 to $3125 \mathrm{~kg} / \mathrm{m}^{3}$, samples of SB group values from 3095 to $3181 \mathrm{~kg} / \mathrm{m}^{3}$ and these of SC group from 3060 to $3169 \mathrm{~kg} / \mathrm{m}^{3}$ (Figure 8a). Samples of SA group display water absorption, which ranges from 0.68 to $1.08 \%$, samples of SB group from 1.01 to $1.59 \%$ and these of SC group from 1.09 to $1.48 \%$ (Figure $8 b$, Table 6). Furthermore, the uniaxial compressive strength (UCS) of the produced concrete specimens was measured. The compressive strength of the standard concrete specimens (produced by natural aggregates) ranges from 36.00 to $38.00 \mathrm{MPa}$ in 7 days and from 47.00 to $48.50 \mathrm{MPa}$ in 28 days (Figure $8 \mathrm{c}$ ). In 7 days, the UCS of SA group ranges from 62.24 to $66.35 \mathrm{MPa}$, while in 28 days ranges from 75.80 to $83.42 \mathrm{MPa}$ simultaneously indicating these samples as those presenting the highest concrete strength (Figure 8c,d, Table 6). As for the SB group, the UCS in 7 days it ranges from 50.02 to $56.91 \mathrm{MPa}$ and from 57.12 to $61.74 \mathrm{MPa}$ in 28 days (Figure 8c,d). The UCS of SC group in 7 days ranges from 45.53 to $55.18 \mathrm{MPa}$ and in 28 days from 52.84 to $66.85 \mathrm{MPa}$ (Figure $8 \mathrm{c}, \mathrm{d}$, Table 6). 

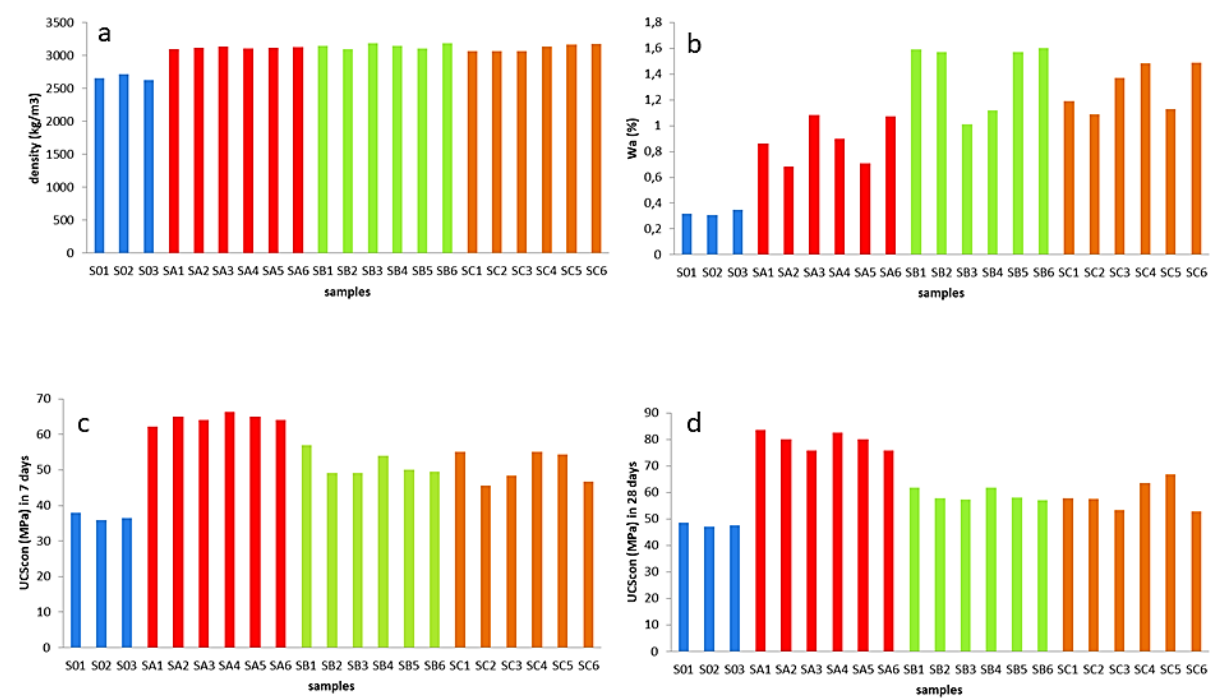

Figure 8. Results of the physical and mechanical properties of the produced concrete specimens. (a) density $\left(\mathrm{kg} / \mathrm{m}^{3}\right)$; (b) Water absorption (\%); (c) Uniaxial compressive strength of 7 days (MPa); (d) Uniaxial compressive strength of 28 days (MPa).

Table 6. Results of the physical and mechanical tests of the produced concrete specimens.

\begin{tabular}{lcccc}
\hline Samples & $\begin{array}{c}\text { Density } \\
\left(\mathbf{k g} / \mathbf{m}^{\mathbf{3}} \mathbf{)}\right.\end{array}$ & $\begin{array}{c}\text { Water } \\
\text { Absorption } \mathbf{( \% )}\end{array}$ & $\begin{array}{c}\text { Uniaxial Compressive } \\
\text { Strength of 7 Days } \\
\mathbf{( M P a )}\end{array}$ & $\begin{array}{c}\text { Uniaxial Compressive } \\
\text { Strength of 28 Days } \\
\mathbf{( M P a )}\end{array}$ \\
\hline S01 & 2650 & 0.32 & 38.00 & 48.50 \\
S02 & 2709 & 0.31 & 36.00 & 47.00 \\
S03 & 2621 & 0.35 & 36.55 & 47.50 \\
SA1 & 3093 & 0.86 & 62.24 & 83.42 \\
SA2 & 3113 & 0.68 & 64.94 & 80.02 \\
SA3 & 3129 & 1.08 & 64.13 & 75.88 \\
SA4 & 3098 & 0.90 & 66.35 & 82.48 \\
SA5 & 3112 & 0.71 & 64.94 & 80.06 \\
SA6 & 3125 & 1.07 & 64.15 & 75.80 \\
SB1 & 3140 & 1.59 & 56.91 & 61.74 \\
SB2 & 3095 & 1.57 & 49.15 & 57.85 \\
SB3 & 3179 & 1.01 & 49.14 & 57.43 \\
SB4 & 3141 & 1.12 & 53.90 & 61.70 \\
SB5 & 3098 & 1.57 & 50.02 & 58.02 \\
SB6 & 3181 & 1.60 & 49.53 & 57.12 \\
SC1 & 3065 & 1.19 & 55.17 & 57.84 \\
SC2 & 3064 & 1.09 & 45.53 & 57.50 \\
SC3 & 3060 & 1.37 & 48.35 & 53.26 \\
SC4 & 3129 & 1.48 & 55.18 & 63.59 \\
SC5 & 3166 & 1.13 & 54.37 & 66.85 \\
SC6 & 3169 & 1.49 & 46.80 & 52.84 \\
\hline
\end{tabular}

As for the concrete specimens made by slags, the presence of fractures between the slags and the cement paste is partially observed (Figure 8). Moreover, samples SA1-SA6 and SC1-SC6 are characterized by satisfactory bonding with the cement paste (Figure $9 \mathrm{a}-\mathrm{d}, \mathrm{f}, \mathrm{h}$ ). On the contrary, samples SB1-SB6 presents lower microroughness and unsatisfactory bonding with the cement paste, which indicated from the zone around wüstite grains which acts as detachment zone during the load (Figure 9e,g). During the petrographic study of the concrete specimens, a large number of wüstite and spinel crystals were found to have been detached from the cement paste on a large scale after loading, while in none of the studied slags crystalline microcracks were found penetrating their mass. The general microroughness of the mineral components of the slags does not show any increase which is likely to work adversely within the concrete. 

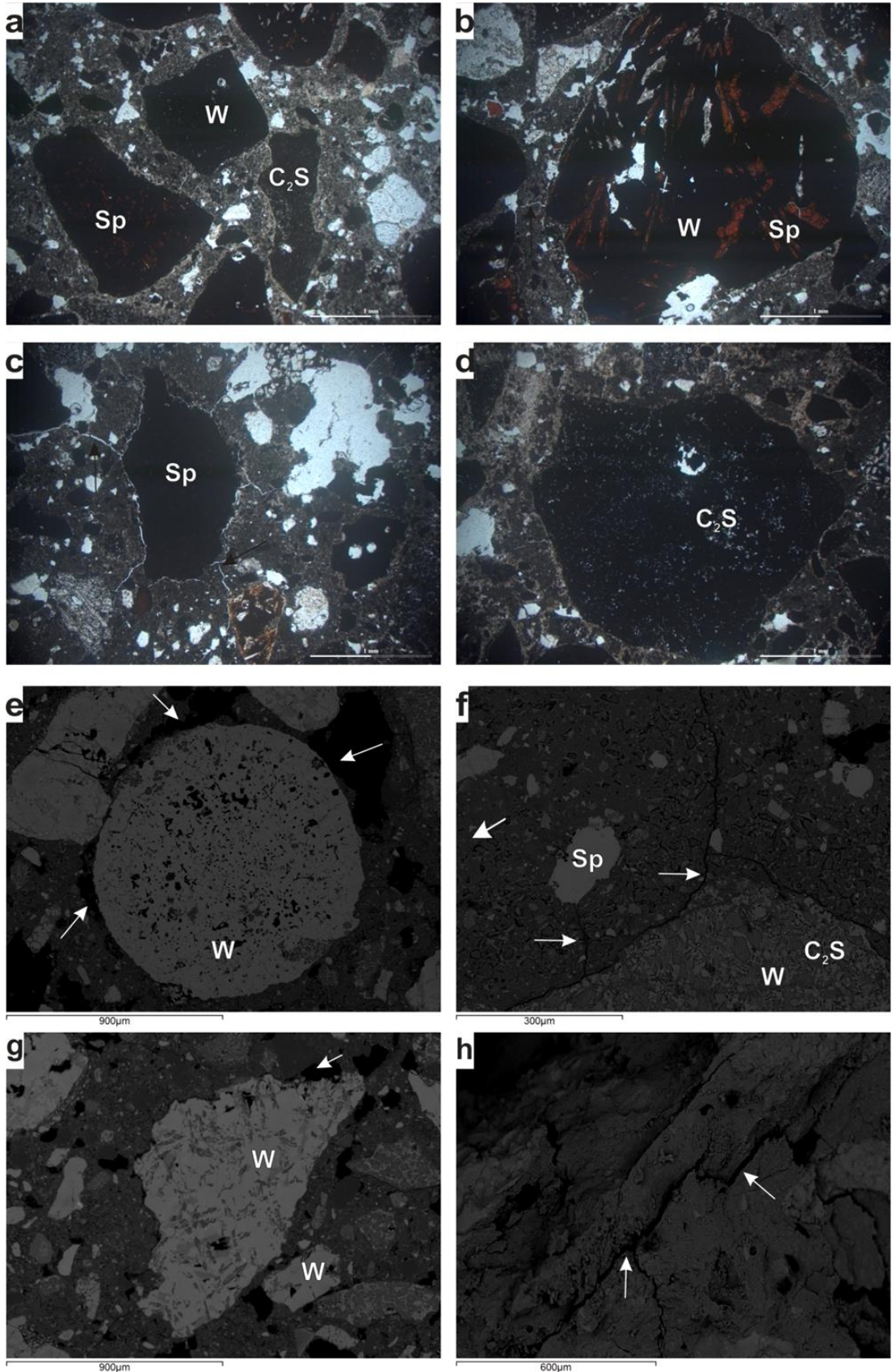

Figure 9. Textural characteristics of the studied concrete specimens: (a) Photomicrograph of subhedral spinel (Sp), wüstite $(\mathrm{W})$ and anhedral calc-silicate phase $\left(\mathrm{C}_{2} \mathrm{~S}\right)$ (PPL Nicols, sample SA1). (b) Photomicrograph of elogated grain of slag consisting of spinel (Sp) and wüstite (W) (PPL Nicols, sample SC2). (c) Photomicrograph of subhedral and elogates spinel (Sp) in which scattered cracks are observed which do not penetrate it (PPL Nicols, sample SC5). (d) Photomicrograph of an elogated grain of ELECTRIC ARC FURNACE SLAG, which contain calc-silicate phase $\left(\mathrm{C}_{2} S\right)$ and has a good cohesion with the cement paste (PPL Nicols, sample SA4). (e) Back-scattered electron image of a spherical grain of wïstite (W) which does not have good cohesion with the cement paste and detachments are observed around it (sample SB6). (f) Back-scattered electron image of cracks in the cement paste and around a grain of an ELECTRIC ARC FURNACE SLAG that contains calc-silicate phase $\left(\mathrm{C}_{2} \mathrm{~S}\right)$ and spherical wüstite (W) (sample SA6). (g) Back-scattered electron image of subhedral w $\ddot{s}$ tite $(\mathrm{W})$ around which detachments are observed (sample SB2). (h) Back-scattered electron image of cracks and detachments between the cement paste and the FeNi slag (sample SC6). 
All the above are enhanced either through the processing of microscopic images after the $3 \mathrm{D}$ depiction or through the study of the transition zone between the aggregate and the cement paste as it is shown in Figure $10 \mathrm{a}-\mathrm{d}$. The grains of $\mathrm{C}_{2} \mathrm{~S}$ phases and spinels (Figure $10 \mathrm{a}, \mathrm{c}, \mathrm{d}$ ) seem to present good cohesion with the cement paste. In addition, it is observed that the grains of wïstite have lower microroughness compared to that of the cement paste, where this alternation of the concrete components leads to the better cohesion among them (Figure 10b).
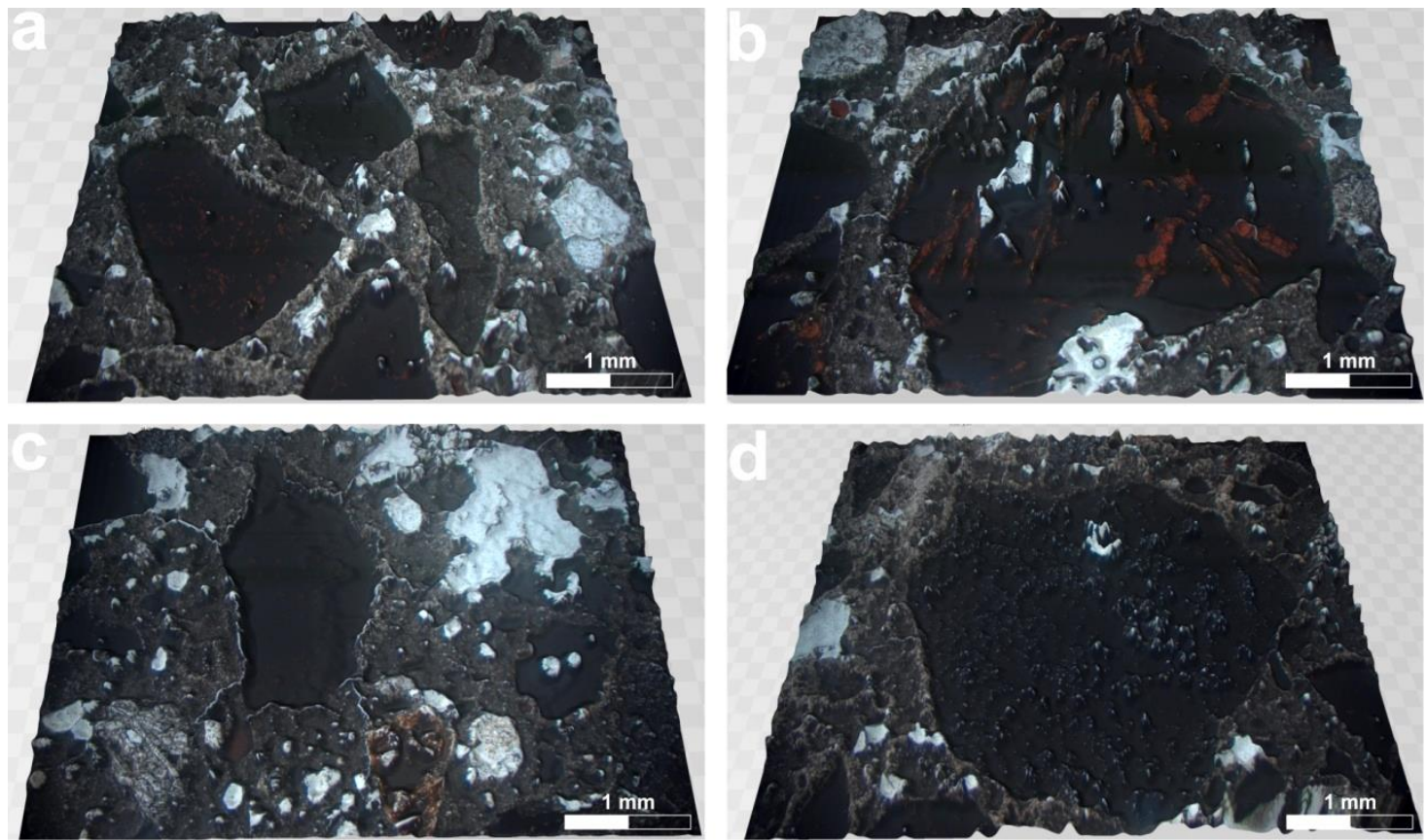

Figure 10. 3D depictions of the investigated concrete specimens: (a) spinel, wüstite and calc-silicate phase (sample SA1); (b) spinel and wüstite (sample SC2); (c) spinel (sample SC5); and (d) calc-silicate phase paste (sample SA4).

\section{Discussion}

Different types of industrial byproducts have been studied in the past few decades in order to find suitable alternatives of natural aggregates in concrete. Blast furnace slag, steel slag, copper slag and foundry slag can be used as concrete aggregates. In this study, different types of slags have been evaluated in various mixtures in order to identify the optimum combination of recycled raw materials such as slags for their use in several construction applications of high demands. For this reason, at the same time, a standard concrete of the same category was prepared containing only natural carbonate aggregates in order to carry out a direct comparative study between these types of concrete specimens so that a wider application of such type of by products could be established. At first, when studying the aggregate properties, significant differences regarding their physical and mechanical properties are identified. More specifically, slags used as aggregates display better properties in terms of their mechanical strength, while limestones present advantages in terms of water absorption and physical properties in order to be used as concrete aggregates. The density of slags used as aggregates appears significantly increased compared to natural aggregates that lead to the characterization of slags as heavy weight aggregates, while the same applies to their density. The water absorption of slags is particularly high compared to that of common limestones used as aggregates. This parameter must be taken into account when studying the composition of concrete, so that no reduced workability can be observed from the absorption of water by the aggregates. Several researchers have studied the influence of the aggregate type on the final concrete strength which is directly depends on their properties [46-48]. During the microscopic study of the raw materials where they 
were studied as aggregates, significant differences are identified both between the natural aggregates and the slags as well as between slags of different origins. More specifically, natural aggregates are less compact and contain numerous microcracks, and thus they penetrate their entire mass compared to slags where they are more compact, and they display less intargranular microcracks. However, the porosity in the micro-scale seems to be increased in the whole of the studied slags in relation to the carbonate rocks in which the porosity is more uniformly distributed, something that probably affects in all the properties but also in their final relationship with the cement paste. However, there are significant differences between the slags during their microscopic observation where the FeNi slags show significantly higher percentage of wüstite and spinel than those of ELECTRIC ARC FURNACE SLAG, while at the same time, the FeNi slags show lower percentage of calc silicate phases than those of the ELECTRIC ARC FURNACE SLAG significantly affecting to the properties of aggregates. Moreover, a significant difference during the microscopic study is found in the porosity which seems to be greater in the FeNi slags in contrast to the corresponding ones of ELECTRIC ARC FURNACE SLAG, something that is mainly attributed to their special mineral characteristics.

Test results of the compressive strength from different concrete mixtures in 7 and 28 days are plotted in Figure $8 \mathrm{c}, \mathrm{d}$. The replacement of limestone aggregates with slags in concrete seems to significantly increase their compressive strength both in 7 and 28 days in all cases. The 28-day compressive strength levels of concrete specimens made by slags as aggregates present range of values from $52 \mathrm{MPa}$ to $83 \mathrm{MPa}$ compared to the corresponding concretes produced only by natural aggregates which do not exceed $40 \mathrm{MPa}$, i.e., much lower than expected, which is initially attributed to the higher hardness of slags as shown in the comparative table with the properties of the aggregates (natural and recycled).

In general, it seems that when slag is used regardless its source in all the aggregate grain sizes, then the density of the mixture can exceed $3000 \mathrm{~kg} / \mathrm{m}^{3}$ in relation to the corresponding concrete specimens which have been produced only by natural raw materials (density values up to $2650 \mathrm{~kg} / \mathrm{m}^{3}$ ). In most cases, however, the use of aggregate slag implies the production of concrete with density greater than $2700 \mathrm{~kg} / \mathrm{m}^{3}$, which must be taken into account when designing such type of constructions. The uniaxial compressive strength of concrete specimens produced by slags is better than of those produced by natural aggregates with an increase of $20 \%$ in concrete with lower percentage of ELECTRIC ARC FURNACE SLAG slag and with higher percentage of FeNi slag. This increase reaches the percentage of $30 \%$ in the cases where it participates in a higher percentage of ELECTRIC ARC FURNACE SLAG slags and a lower percentage of FeNi slags. This is due to all the special characteristics of the slags in relation to their physical and especially to their mechanical characteristics directly dependent on their microscopic characteristics where slags present a compact texture without microcracks and uniformly distributed porosity which seems to affect the smooth crystallization process of the cement and therefore on its stronger bonding with the aggregates in relation to the unevenly distributed porosity of the natural aggregates. During the petrographic study of concrete, when studying the micro scale where the failures are born, significant differences in the microcracks' process are identified after the breaking of the concrete specimens. During the microscopic study of the oriented thin sections during the uniaxial compressive strength test of concrete specimens produced by natural aggregates microcracks are shown to break the carbonate aggregates trangranularly and intragranularly, something that in concrete specimens made by slags was not found in any of the examined mixtures. This fact is attributed to both mechanical of aggregate materials as well as in their mineralogical characteristics. Among the mixtures produced by different types of slags, significant differences in their mechanical strength were observed. The differences in the final compressive strength of the produced concretes are observed as significant even with small variations in the percentage participation of the different types of slag, something that reveals the strong influence of the special mineralogical characteristics on the final quality of the produced concrete specimens. 
The superiority of mixtures of SA group in contrast to that of SB group (higher percentage of ELECTRIC ARC FURNACE SLAG slag) and that of SC group (lower percentage of natural sand) is evident both in 7 days and in 28 days of curing. This difference on the final concrete strength where different types of slags are participated is precisely related to their different weights and their different densities as the slag aggregates which are characterized as heavy weight aggregates produce heavy weight type concretes and as their weight increases it seems their durability to be reduced linearly.

The differences in all properties of the produced concretes which are identified between the groups SA, SB, SC can be interpreted by studying and evaluating the particular microscopic characteristics of both raw materials (slags and natural rocks) and the produced concrete specimens. The hydration of ladle slags with a content of hydraulically active mineral and the glass phase is taking place after adding water, without having to supply an alkali-activator. The hydraulic properties of slags are incommensurable compared to Portland cement however hydrating abilities are affected by the chemical composition. Samples SB do not present high compressive strength, while the other samples present better compressive strength after 28 days of hydration. Samples in which compressive strength values are higher than those of SB group contain mineral dicalcium silicate in this group. This mineral occurs in Portland clinker [1] and due to its hydration there are the so [32] called C-S-H phases formed. These phases are bearers of strength in the hydrated cement. Additionally, it is evident that mixtures containing higher amount of ELECTRIC ARC FURNACE SLAG slag and lower amount of FeNi slag (SA and SC group) yield increased mechanical concrete properties compared to the SB group, which seems to be related to the increased concentration of w $\ddot{v}$ stite and mervinite in FeNi slags (Tables 1 and 2). The presence of wüstite in the concrete as it was detected through the microscopic study seems to act as a surface of weakness within the structure of the cement paste as the cubic system to which it belongs creates some plan surfaces capable of acting as levels of failure during uniaxial loads. The fact of the negative effect mainly of wüstite on the final mechanical strength of concrete specimens is documented both by the microscope images and by the three-dimensional study of the produced concretes. More specifically, as shown in Figure 9b, an extensive zone of detachment from the adhesive cement is located around the wüstite, which is found throughout the range of concrete. This fact indicates the existence of a point of weakness inside the concrete where during the uniaxial loading they act exactly as detachment points resulting in faster breaking. In addition, as shown in the three-dimensional study, the wüstite crystals do not show a particularly significant microtopography in relation to the rest of the mortar, while at the same time it presents extensive flat areas which may also function as slip levels during loading. The spinel shows similar behavior to wüstite as shown in Figures 8a and 9a. In contrast to wüstite and spinel, the presence of $\mathrm{C}_{2} \mathrm{~S}$ phases seems to have a significant positive effect on the mechanical concrete strength as no significant detachment zones are found perimetrically during the fracture while the three-dimensional microtopography seems to be satisfactory and evenly distributed throughout the surface (Figure 9d) creating formations which seem to mechanically trap the cement mortar. An extra significant parameter for uniaxial compressive strength of concrete with the increased percentage of FeNi slags seems to be the existence of merwinite when is regarded as a low hydraulically active mineral $[49,50]$. It seems to significantly affect the hydraulic properties of the cement and its smooth hydration reaction, resulting in a significant reduction in its mechanical strength and around these crystals to identify areas of reaction and weakness.

As it is shown through the study of the X-ray diffraction patterns of raw materials it seems that the compressive strength of samples prepared from the slags Electric Arc Furnace Slag were secured primarily by the presence of $b-C_{2} S$ phase. The $b-C_{2} S$ phase is considered the most important for ensuring the strength of products with water activated ladle slags. The Electric Arc Furnace Slag slags which after adding water have sufficient strength are in accordance with condition C/S. The low ratio C/S shows these slags which is hydraulically inactive. The other type of slags has a satisfactory $\mathrm{C} / \mathrm{S}$ ratio but its hydraulicity is low. 
Additionally, in contrast to mervinite and wïstite, the presence of gelenite in an increased percentage in the ELECTRIC ARC FURNACE SLAG slag seems to have a significant effect on both the properties of slags and on the behavior of the produced concrete. As can be seen through the microscopic study of the microstructure of concrete, strong adhesion with the cement paste is detected, which is probably due to the partial hydration reaction of these mineral phases and its special morphological characteristics. Additionally, the difference between FeNi and ELECTRIC ARC FURNACE SLAG slag can be observed not only in their mineralogical composition but also in their chemical composition and thus even the study of their chemical composition could potentially be used as a predictor of slag behavior in concrete. More specifically, FeNi slags show intensively lower percentage of free $\mathrm{CaO}$ compared to their respective ELECTRIC ARC FURNACE SLAG slag participation and the diversity in their composition confirms the strong heterogeneity of these slags and imbalances in their solidification the hardening of the hydrated slags is also involved in the presence of the amorphous phase, especially in the case of slags containing free $\mathrm{CaO}$ as Calcium hydroxide is the activator of the latent hydraulicity for the amorphous phase [51].

\section{Conclusions}

This paper examines industrial byproducts (ferronickel slags) to evaluate their suitability as concrete aggregates, with the ultimate goal of the production of environmentally friendly concrete from now on. The main conclusions of this study are given in the remarks below:

$>$ The determinant factor for the final mechanical behavior of concrete seems to be the mineralogical and microstructural characteristics of slags used as aggregates. In contrast to wüstite and spinel, the presence of $\mathrm{C}_{2} \mathrm{~S}$ phases seems to have a significant positive effect on the concrete strength as no significant detachment zones are found perimetrically during the fracture.

$>$ Natural aggregates are less compact as they contain numerous microcracks and hence they penetrate their entire mass compared to slags where they are more compact and they display less intargranular microcracks, making them suitable for concrete aggregates.

$>$ The participation of slags in concrete mixtures improves their mechanical strength as the replacement of limestone aggregates with slags in concrete seems to significantly increase their compressive strength both in 7 and 28 days in all mixtures.

$>$ Mixtures containing higher amount of ELECTRIC ARC FURNACE SLAG slag due to their lower concentration of wüstite and mervinite present increased mechanical concrete properties.

Author Contributions: Conceptualization, P.P.; methodology, P.P., A.R., P.P.G. and P.L.; software, P.P., A.R. and A.C.; investigation, P.P., A.R., P.P.G., A.C., S.L. and P.L.; resources, P.P., P.P.G., A.C. and P.L.; data curation, P.P., A.R., P.P.G., A.C. and P.L.; writing—original draft preparation, P.P. and P.P.G.; writing - review and editing, P.P., A.R., P.P.G. and N.K.; visualization, P.P. and P.K.; supervision, P.P. All authors have read and agreed to the published version of the manuscript.

Funding: This research received no external funding.

Institutional Review Board Statement: Not applicable.

Informed Consent Statement: Not applicable.

Conflicts of Interest: The authors declare no conflict of interest.

\section{References}

1. ISO/TC 071; Strategic Business Plan. ISO: Tokyo, Japan, 2016.

2. World Population Clock: 7.9 Billion People (2021)—Worldometer. Available online: https://www.worldometers.info/worldpopulation/ (accessed on 7 December 2021).

3. Saha, A.K.; Khan, M.N.N.; Sarker, P.K. Value added utilization of by-product electric furnace ferronickel slag as construction materials: A review. Resour. Conserv. Recycl. 2018, 134, 10-24. [CrossRef] 
4. Andrew, R.M. Global $\mathrm{CO}_{2}$ emissions from cement production. Earth Syst. Sci. Data 2018, 10, 195-217. [CrossRef]

5. Kosmatka, S.K.; Kerkhoff, B.; Panarese, W.C. Design and Control of Concrete Mixtures, 14th ed.; Portland Association: Skokie, IL, USA, 2002; ISBN 0-89312-217-3.

6. Paris Agreement. Available online: https://ec.europa.eu/clima/eu-action/international-action-climate-change/climatenegotiations/paris-agreement_el (accessed on 14 December 2021).

7. Circular Economy Action Plan. Available online: https://ec.europa.eu/environment/strategy/circular-economy-action-plan_en (accessed on 14 December 2021).

8. Directive, E.C. Directive 2008/98/EC of the European Parliament and of the Council of 19 November 2008 on waste and repealing certain Directives (Text with EEA relevance). Off. J. Eur. Union 2008, 312, 3-30.

9. Directive (Eu) 2018/851 of the European Parliament and of the Council of 30 May 2018 amending Directive 2008/98/EC on waste (Text with EEA relevance). Off. J. Eur. Union 2018, 150, 109-140.

10. Van Oss, H.G. Slag-Iron and Steel, U.S. Geological Survey, Minerals Yearbook 2017; USGS: Reston, VA, USA, 2017.

11. Statistics 2018-Euroslag. Available online: https://www.euroslag.com/products/statistics/statistics-2018/ (accessed on 16 December 2021).

12. Bartzas, G.; Komnitsas, K. Life cycle assessment of ferronickel production in Greece. Resour. Conserv. Recycl. 2015, 105, 113-122. [CrossRef]

13. Criado, M.; Ke, X.; Provis, J.L.; Bernal, S.A. Alternative Inorganic Binders Based on Alkali-Activated Metallurgical Slags; Woodhead Publishing: Sawston, UK, 2017; ISBN 9780081020029.

14. Saha, A.K.; Sarker, P.K. Sustainable use of ferronickel slag fine aggregate and fly ash in structural concrete: Mechanical properties and leaching study. J. Clean. Prod. 2017, 162, 438-448. [CrossRef]

15. Dong, Q.; Wang, G.; Chen, X.; Tan, J.; Gu, X. Recycling of steel slag aggregate in Portland cement concrete: An overview. J. Clean. Prod. 2021, 282, 124447. [CrossRef]

16. Małek, M.; Jackowski, M.; Łasica, W.; Dydek, K.; Boczkowska, A. An Experimental Study of Possible Post-War Ferronickel Slag Waste Disposal in Szklary (Lower Silesian, Poland) as Partial Aggregate Substitute in Concrete: Characterization of Physical, Mechanical, and Thermal Properties. Materials 2021, 14, 2552. [CrossRef]

17. Palankar, N.; Ravi Shankar, A.U.; Mithun, B.M. Durability studies on eco-friendly concrete mixes incorporating steel slag as coarse aggregates. J. Clean. Prod. 2016, 129, 437-448. [CrossRef]

18. Manso, J.M.; Polanco, J.A.; Losañez, M.; González, J.J. Durability of concrete made with EAF slag as aggregate. Cem. Concr. Compos. 2006, 28, 528-534. [CrossRef]

19. Chatzopoulos, A.; Sideris, K.K.; Tassos, C. Production of concretes using slag aggregates: Contribution of increasing the durability and sustainability of constructions. Case Stud. Constr. Mater. 2021, 15, e00711. [CrossRef]

20. Patra, R.K.; Mukharjee, B.B. Influence of incorporation of granulated blast furnace slag as replacement of fine aggregate on properties of concrete. J. Clean. Prod. 2017, 165, 468-476. [CrossRef]

21. Anastasiou, E.; Georgiadis Filikas, K.; Stefanidou, M. Utilization of fine recycled aggregates in concrete with fly ash and steel slag. Constr. Build. Mater. 2014, 50, 154-161. [CrossRef]

22. Kim, H.; Lee, C.H.; Ann, K.Y. Feasibility of ferronickel slag powder for cementitious binder in concrete mix. Constr. Build. Mater 2019, 207, 693-705. [CrossRef]

23. Sun, J.; Feng, J.; Chen, Z. Effect of ferronickel slag as fine aggregate on properties of concrete. Constr. Build. Mater. 2019, 206, 201-209. [CrossRef]

24. Nuruzzaman, M.; Kuri, J.C.; Sarker, P.K. Strength, permeability and microstructure of self-compacting concrete with the dual use of ferronickel slag as fine aggregate and supplementary binder. Constr. Build. Mater. 2022, 318, 125927. [CrossRef]

25. Yuan, S.; Liu, X.; Gao, P.; Han, Y.X. A semi-industrial experiment of suspension magnetization roasting technology for separation of iron minerals from red mud. J. Hazard. Mater. 2020, 394, 122579. [CrossRef]

26. Wu, Q.; Chen, Q.; Huang, Z.; Gu, B.; Zhu, H.; Tian, L. Preparation and characterization of porous ceramics from nickel smelter slag and metakaolin. Ceram. Int. 2020, 46, 4581-4586. [CrossRef]

27. Xi, B.; Li, R.; Zhao, X.; Dang, Q.; Zhang, D.; Tan, W. Constraints and opportunities for the recycling of growing ferronickel slag in China. Resour. Conserv. Recycl. 2018, 139, 15-16. [CrossRef]

28. Pan, J.; Zheng, G.; Zhu, D.; Zhou, X. Utilization of nickel slag using selective reduction followed by magnetic separation. Trans. Nonferrous Met. Soc. China 2013, 23, 3421-3427. [CrossRef]

29. Liu, X.; Feng, Y.; Li, H.; Yang, Z.; Cai, Z. Recovery of valuable metals from a low-grade nickel ore using an ammonium sulfate roasting-leaching process. Int. J. Miner. Metall. Mater. 2012, 19, 377-383. [CrossRef]

30. Yang, H.; Jing, L.; Zhang, B. Recovery of iron from vanadium tailings with coal-based direct reduction followed by magnetic separation. J. Hazard. Mater. 2011, 185, 1405-1411. [CrossRef]

31. Rashad, A.M.; Sadek, D.M.; Hassan, H.A. An investigation on blast-furnace stag as fine aggregate in alkali-activated slag mortars subjected to elevated temperatures. J. Clean. Prod. 2016, 112, 1086-1096. [CrossRef]

32. Sato, T.; Watanabe, K.; Ota, A.; Aba, M.; Sakoi, Y. Influence of Excessive Bleeding on Frost Susceptibility of Concrete Incorporating Ferronickel Slag as Aggregates. In Proceedings of the 36th Conference on Our World in Concrete and Structures, Singapore, 25-27 August 2011; Available online: www.cipremier.com/e107_files/downloads/Papers/100/36/100036049.pdf (accessed on 10 May 2015). 
33. Tomosawa, F.; Nagataki, S.; Kajiwara, T.; Yokoyama, M. Alkali-aggregate Reactivity of Ferronickel-slag Aggregate Concrete. Spec. Publ. 1997, 170, 1591-1602.

34. Shoya, M.; Aba, M.; Tsukinaga, Y.; Tokuhashi, K. Frost resistance and air void system of self-compacting concrete incorporating slag as a fine aggregate. Spec. Publ. 2003, 212, 1093-1108.

35. Wang, G.; Thompson, R.; Wang, Y. Hot-mix asphalt that contains nickel slag aggregate: Laboratory evaluation of use in highway construction. Transp. Res. Rec. J. Transp. Res. Board 2011, 2208, 1-8. [CrossRef]

36. Fidancevska, E.; Vassilev, V.; Milosevski, M.; Parvanov, S.; Milosevski, D.; Aljihmani, L. Composites based on industrial wastes III. Production of composites of Fe-ni slag and waste glass. J. Univ. Chem. Technol. Metal 2007, 42, 285-290.

37. ASTM C 150; Standard Specification for Portland Cement. ASTM International: West Conshohocken, PA, USA, 2017.

38. EN 932; Part 3: Procedure and Terminology for Simplified Petrographic Description. European Standard: Warsaw, Poland, 1996.

39. ASTM D 7348; Standard Test. Methods for Loss on Ignition (LOI) of Solid Combustion. Residues. ASTM International: West Conshohocken, PA, USA, 2013.

40. ASTM C1567; Standard Test Method for Determining the Potential Alkali-Silica Reactivity of Combinations of Cementitious Materials and Aggregate (Accelerated Mortar-Bar Method). ASTM International: West Consohohoken, PA, USA, 2013.

41. ACI-211.1-91; Standard for Selecting Proportions for Normal, Heavyweight and Mass Concrete. American Concrete Institute: Farmington Hills, MI, USA, 2002.

42. ASTM C42/C42M-12; Standard Test. Method for Obtaining and Testing Drilled Cores and Sawed Beams of Concrete. ASTM International: West Conshohocken, PA, USA, 2013.

43. ASTM C856; Standard Practice for Petrographic Examination of Hardened Concrete. American Society for Testing and Materials: West Conshohocken, PA, USA, 2017.

44. BS 812; Methods for Sampling and Testing of Mineral. Aggregates, Sands and Fillers, Part. 1: Methods for Determination of Particle Size and Shape. British Standard Institution: London, UK, 1975.

45. ASTM Standard C642; Standard Test Method for Density, Absorption, and Voids in Hardened Concrete. ASTM International: West Conshohocken, PA, USA, 2006. [CrossRef]

46. Petrounias, P.; Giannakopoulou, P.P.; Rogkala, A.; Stamatis, P.M.; Tsikouras, B.; Papoulis, D.; Lampropoulou, P.; Hatzipanagiotou, K. The Influence of Alteration of Aggregates on the Quality of the Concrete: A Case Study from Serpentinites and Andesites from Central Macedonia (North Greece). Geosciences 2018, 8, 115. [CrossRef]

47. Petrounias, P.; Giannakopoulou, P.P.; Rogkala, A.; Lampropoulou, P.; Tsikouras, B.; Rigopoulos, I.; Hatzipanagiotou, K. Petrographic and Mechanical Characteristics of Concrete Produced by Different Type of Recycled Materials. Geosciences 2019,9 , 264. [CrossRef]

48. Petrounias, P.; Rogkala, A.; Giannakopoulou, P.P.; Lampropoulou, P.; Xanthopoulou, V.; Koutsovitis, P.; Koukouzas, N.; Lagogiannis, I.; Lykokanellos, G.; Golfinopoulos, A. An Innovative Experimental Petrographic Study of Concrete Produced by Animal Bones and Human Hair Fibers. Sustainability 2021, 13, 8107. [CrossRef]

49. Muhmood, L.; Vitta, S.; Venkateswaran, D. Cementitious and pozzolanic of electric arc furnace steel slags. Cem. Concr. Res. 2009, 39, 102-109. [CrossRef]

50. Adolfsson, D.; Robinson, R.; Engström, F.; Björkman, B. Influence of mineralogy on the hydraulic properties of ladle slag. Cem. Concr. Res. 2011, 41, 865-871. [CrossRef]

51. Arnout, L.; Beersaerts, G.; Liard, M.; Lootens, D.; Pontikes, Y. Valorising Slags from Non-ferrous Metallurgy into Hybrid Cementitious Binders: Mix Design and Performance. Waste Biomass Valor. 2021, 12, 4679-4694. [CrossRef] 